\title{
NOWA METODA TUNELOWEGO WYZNACZANIA MACIERZY WRAŻLIWOŚCI DLA POTRZEB PROCESU REKONSTRUKCJI OBRAZÓW DLA TRÓJWYMIAROWEJ TOMOGRAFII POJEMNOŚCIOWEJ
}

\author{
Radosław Wajman, Robert Banasiak \\ Instytut Informatyki Stosowanej Politechniki Łódzkiej, Łódź, Polska
}

Streszczenie. Macierz wrażliwości jest głównym czynnikiem wplywajacym na finalna jakość wyników procesu rekonstrukcji obrazów dla trójwymiarowej elektrycznej tomografii pojemnościowej 3D ECT. Dotychczasowe metody ich wyznaczania daja w większości przypadków dobre wyniki rekonstrukcji $i$ umożliwiaja dodatkowo wykonanie procesu iteracyjnej aktualizacji map wrażliwości, dostosowując ich naturę do zmieniajacego się wraz $z$ procesem rekonstrukcji symulowanego rozkładu pola elektrycznego. $W$ ramach niniejszego artykułu autorzy przedstawia własna istotna modyfikację procesu wyznaczania map wrażliwości poprzez uwzględnienie w tym procesie szczegółowego rozkładu pola we wnętrzu czujnika. Opracowany nowy tunelowy algorytm wyznaczania macierzy wrażliwości konstruuje mapy wrażliwości w oparciu o śledzenie powierzchni budowanych wzdluż linii sił pola elektrycznego. W artykule zostana przedstawione wyniki procesu rekonstrukcji obrazów, które wykaża większa skuteczność nowej metody.

Słowa kluczowe: 3D ECT, tomografia pojemnościowa, rekonstrukcja obrazu, macierz wrażliwości, MES

\section{NEW TUNNEL BASED METHOD OF SENSITIVITY MATRIX CALCULATION FOR 3D CAPACITANCE TOMOGRAPHY IMAGE RECONSTRUCTION}

\begin{abstract}
The sensitivity matrix is main part of the image reconstruction process for 3D ECT imaging and strictly decides about the its final quality. Common sensitivity determination methods mostly provide acceptable results and additionally allow to perform the recalculation of the sensitivities according to the changing permittivity distribution. In this paper authors introduce the crucial modification of the sensitivity determination process based on the electric field distribution analysis. The designed new tunnel based algorithm follows the surfaces constructed along the electric field lines. In the paper the results of the image reconstruction experiments will be shown and the better accuracy of the new method will be proved.
\end{abstract}

Keywords: 3D ECT, capacitance imaging, sensitivity matrix, FEM

\section{Wprowadzenie}

Macierz wrażliwości jest głównym czynnikiem wpływającym na finalną jakość wyników procesu rekonstrukcji obrazów dla trójwymiarowej elektrycznej tomografii pojemnościowej 3D ECT (ang. three dimensional electrical capacitance tomography) $[5,9,10]$. Najbardziej znaną i stosowaną w praktyce metodą jej wyznaczania jest algorytm obliczania map wrażliwości w oparciu o zależności matematyczno-fizyczne wynikające z fizyki pola elektrycznego [4]. Algorytm ten daje w większości przypadków dobre wyniki rekonstrukcji i umożliwia dodatkowo wykonanie procesu iteracyjnej aktualizacji map wrażliwości, dostosowując ich nature do zmieniającego się wraz z procesem rekonstrukcji rozkładu pola elektrycznego. W ramach niniejszego artykułu autorzy przedstawią istotną modyfikację procesu wyznaczania map wrażliwości poprzez uwzględnienie w tym procesie szczegółowego rozkładu pola we wnętrzu czujnika.

Opracowany i zaimplementowany tunelowy algorytm wyznaczania macierzy wrażliwości w każdej iteracji procesu rekonstrukcji konstruuje mapy wrażliwości w oparciu o śledzenie powierzchni budowanych wzdłuż linii sił pola elektrycznego. W artykule zostanie wykazane, iż nowe mapy wrażliwości znacznie dokładniej oddają nieliniową naturę pola elektrycznego, a metoda ich wyznaczania została nazwana metodą tunelową z uwagi na geometryczny kształt generowanych rozkładów wrażliwości.

\section{Proces rekonstrukcji trójwymiarowych obrazów tomograficznych}

Mechanizm budowania obrazu dla potrzeb wizualizacji procesów przemysłowych przy użyciu elektrycznej tomografii pojemnościowej określany jest jako rekonstrukcja (bądź konstrukcja) obrazu. W praktyce proces ten może mieć charakter liniowy lub nieliniowy. W pierwszym przypadku rekonstrukcja obrazu jest wyznaczana bezpośrednio (deterministyczne metody projekcji wstecznej lub techniki regularyzacyjne [12]), bądź też na drodze optymalizacji iteracyjnej przy użyciu stałego symulowanego rozkładu wrażliwości w komputerowym modelu czujnika [2]. W drugim przypadku (rozważanym w ramach niniejszego artykułu) proces przebiega w schemacie iteracyjnym i uwzględnia nieliniowy charakter pola elektrycznego. Nieliniowość pola elektrycznego w procesie rekonstrukcji obrazów oraz kształtów można aproksymować poprzez numeryczną symulację działania tomografu pojemnościowego w każdym (bądź tylko w wybranym) kroku iteracyjnym. W tym przypadku stosuje się najczęściej metodę elementów skończonych (MES) lub objętości skończonych [7, 14]. Nieliniowość można również aproksymować poprzez aktualizację modelu wrażliwościowego czujnika woparciu o poprzednio zrekonstruowane obrazy 3D. W ogólnym ujęciu nieliniowy proces rekonstrukcji obrazu przebiega dwuetapowo: w cyklu iteracyjnym rozwiązywane są naprzemiennie dwa zagadnienia: proste i odwrotne. Zagadnienie proste w tomografii pojemnościowej 3D związane jest $\mathrm{z}$ trójwymiarowym numerycznym modelowaniem pola elektrycznego np. poprzez zastosowanie MES. Podstawowym celem tego etapu jest wyznaczenie map wrażliwości czujnika ECT. Wartość wrażliwości w określonym obszarze czujnika definiowana jest jako zmiana wartości pojemności międzyelektrodowej jako odpowiedź na zmianę rozkładu przenikalności w tym konkretnym obszarze. Ta właściwość pola elektrycznego decyduje o tym, że zagadnienie odwrotne jest źle postawione. Powstała na tym fundamencie macierz współczynników $J$ (macierz Jacobiego) jest najważniejszym elementem deterministycznego zagadnienia odwrotnego. Jej zadaniem jest linearyzacja pola elektrycznego i wyznaczenie obrazu rozkładu przenikalności $\boldsymbol{\varepsilon}$ na podstawie wartości pomiarowych $\mathbf{C}[11,12])$.

$$
\boldsymbol{\varepsilon}=\mathbf{J}^{+} \cdot \mathbf{C}
$$

$\mathrm{Z}$ macierzą wrażliwości związanych jest szereg problemów numerycznych. Część $\mathrm{z}$ nich wynika $\mathrm{z}$ faktu, iż macierz wrażliwości nie jest macierzą kwadratową [13]. Jej wymiary zależą od liczby niezależnych pomiarów oraz od znaczaco większej (w szczególności dla zagadnienia 3D) liczby punktów obrazu. Stąd, z matematycznego punktu widzenia, nie jest możliwe wyznaczenie jej odwrotności [13]. W praktyce, w różnych znanych metodach rekonstrukcji obrazów stosowana jest pseudo-odwrotność macierzy wrażliwości, a rozważany problem jest źle uwarunkowany. Wyznaczoną na etapie rozwiązywania zagadnienia prostego macierz wrażliwości stosuje się w drugim z etapów procesu rekonstrukcji obrazu: zagadnieniu odwrotnym. 
Zagadnienie odwrotne w swojej najbardziej złożonej numerycznie postaci (uwzględniającej nieliniowość pola elektrycznego oraz komputerową symulację tomografu i kompletny model numeryczny czujnika pojemnościowego) można zapisać w postaci równania macierzowego - funkcji optymalizującej iteracyjnie obraz $\boldsymbol{\varepsilon}_{3 \mathrm{D}}$ w oparciu o wektor danych pomiarowych $\mathbf{C m}_{3 D}$ :

$\boldsymbol{\varepsilon}_{3 \mathrm{D}}(k+1)=\boldsymbol{\varepsilon}_{3 \mathrm{D}}(k)+R F \cdot \mathbf{J}^{+}\left(\mathbf{V}_{k}\right)\left(\mathbf{C m}_{3 D}-F E M\left(\boldsymbol{\varepsilon}_{3 D}(k)\right)\right)$

gdzie:

$\boldsymbol{\varepsilon}_{3 \mathbf{D}}(k+1)$ - nowy zrekonstruowany obraz 3D,

$\boldsymbol{\varepsilon}_{3 \mathrm{D}}(k)$ - poprzednio zrekonstruowany obraz 3D,

RF - parametr procesu zbieżności,

$\mathbf{J}^{+}\left(\mathbf{V}_{k}\right)$ - aktualizowana iteracyjnie macierz wrażliwości

(nieliniowość pola elektrycznego),

$\mathbf{C m}_{3 D}$ - wektor danych pomiarowych,

$\operatorname{FEM}\left(\boldsymbol{\varepsilon}_{3 \mathrm{D}}(k)\right)$ - komputerowa symulacja tomografu w oparciu o poprzednio zrekonstruowany obraz 3D.

Powyższe równanie stanowi kluczowy element procesu rekonstrukcji obrazów 3D zastosowany w ramach realizacji badań do niniejszego artykułu [1, 4]. Proces ten można również przedstawić w postaci algorytmicznej sieci działań - rysunek 1 .

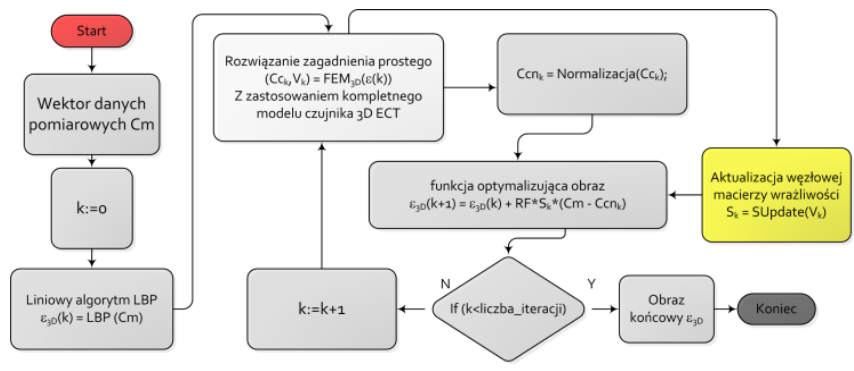

Rys. 1. Sieć działań algorytmu nieliniowej rekonstrukcji obrazu

\section{Metoda tunelowa wyznaczania macierzy wrażliwości}

Algorytm tunelowy bazuje na tym, że większość z deterministycznych metod rekonstrukcji obrazów, które stosują w swoich obliczeniach rozkłady wrażliwości, jest wyprowadzona bezpośrednio z tomografii liniowej tzw. ,hard field tomography”, reprezentowanej przez np. tomografię rentgenowską czy też metody optyczne. Możliwość zaadoptowania tych metod rekonstrukcji dla potrzeb tomografii elektrycznej (reprezentującej rodzinę „soft field” [4, 8]) jest uwarunkowana odpowiednio wyznaczoną macierzą wrażliwości, która, jak już wspomniano, aproksymuje podstawowe właściwości pola elektrycznego wewnątrz układu czujników ECT. W tomografii liniowej analiza wrażliwości polega na wyznaczeniu współczynnika osłabienia każdej projekcji promienia. Współczynnik ten jest wynikiem sumy iloczynu funkcji rozkładu własności fizycznych materiału wewnątrz czujnika $\mathrm{z}$ wagami stanowiącymi udział wszystkich wokseli (definiowanych jako elementy trójwymiarowego obrazu) w biegu danego promienia.

Pole elektryczne wewnątrz czujnika ECT opisane jest równaniem Laplace’a [1]. Dla danego rozkładu przenikalności elektrycznej $\varepsilon(x, y, z)$ i warunków granicznych dla rozkładu potencjałów $\varphi(x, y, z)$, należy znaleźć funkcję polową wykorzystując metody numeryczne jak np. MES. Rozkład potencjałów pola elektrycznego wyznaczony przy pomocy analizy numerycznej dla dowolnego rozkładu materiału wewnątrz czujnika ECT jest silnie zaburzany. Widać to doskonale wyznaczając przebieg linii sił pola elektrycznego. Niech $\vec{\sigma}(l)$ oznacza ścieżkę linii pola elektrycznego, która jest zdefiniowana jako:

$$
\frac{d}{d l} \vec{\sigma}(l)=-\frac{\vec{E}}{|\vec{E}|}=-\frac{\nabla \varphi}{|\nabla \varphi|}
$$

gdzie $l$ jest długością (po łuku) linii $\vec{\sigma}$.

Pochodna wyznacza kierunek gradientu potencjału. Jedną mapę wrażliwości należy budować podążając za spadkiem potencjału począwszy od każdego woksela stanowiącego krawędź elektrody uziemionej (ang. grounded - G) - rysunek 2 .

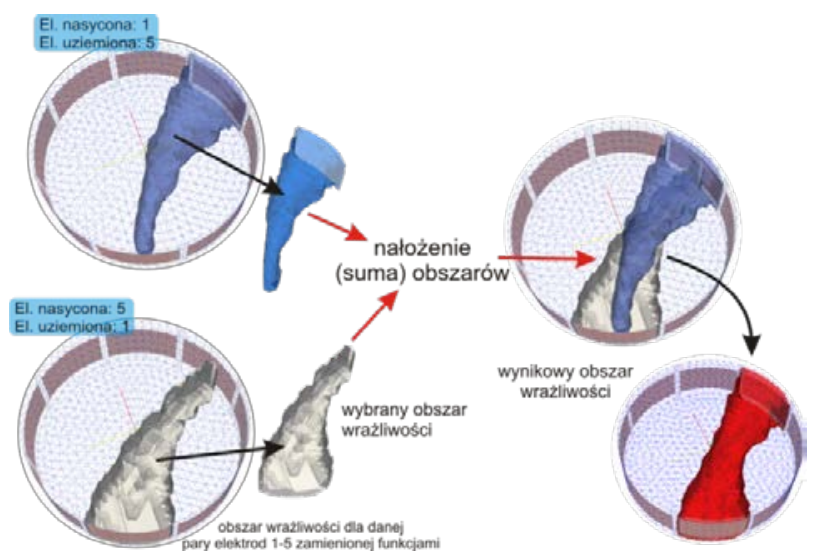

Rys. 2. Idea konstruowania tunelu wrażliwości dla jednej pary elektrod

Wyznaczanych jest szereg linii sił pola elektrycznego. Każda $\mathrm{z}$ linii prowadzi aż do elektrody $\mathrm{z}$ ustawionym potencjałem nasyconej (ang. excited - E). Wszystkie linie zawsze dotrą do elektrody nasyconej i nigdy nie wyjdą poza badany obszar czujnika ECT. W kolejnym etapie algorytmu pomiędzy sąsiednimi liniami odnajdywane są powierzchnie, które w efekcie tworzą tunel zwężający się w kierunku elektrody nasyconej. Następnie podobny tunel wyznaczany jest w oparciu o rozkład potencjałów wyliczony dla przypadku, gdy elektroda będąca do tej pory nasyconą staje się uziemioną, a dotychczasowa uziemiona staje się nasyconą. W efekcie końcowym objętości powstałych $\mathrm{w}$ ten sposób dwóch tuneli są ze sobą łączone w jeden tunel, który dalej jest traktowany jako spójny obszar wrażliwości dla jednej rozważanej pary elektrod oznaczanej tutaj symbolem E-G.

Proces wyznaczania podwójnego tunelu musi być teraz powtarzany dla każdej możliwej pomiarowej pary elektrod bez powtórzeń (E-G). Należy tu zaznaczyć, że bieg wszystkich linii, a w konsekwencji całego tunelu, jest zakłócany poprzez rozkład materiału. Żadna $z$ linii nie jest prosta, lecz jej kształt jest funkcją rozkładu przenikalności. Jest to zgodne z tzw. „efektem pola miękkiego". Rysunek 3 (na następnej stronie) przedstawia sieć działań algorytmu metody tunelowej $\mathrm{z}$ uwzględnieniem wszystkich możliwych par pomiarowych elektrod (bez powtórzeń).

Ta cześć algorytmu musi być realizowana za każdym razem przed przystapieniem do właściwego wyznaczania macierzy wrażliwości, ponieważ zależy nie tylko od geometrii układu ECT ale również od rozkładu materiału w jego wnętrzu. Warto wspomnieć, że znaczne przyspieszenie algorytmu metody tunelowej dla siatki czworościennej można uzyskać po uprzednim wyznaczeniu, dla każdego elementu tej siatki, jego sąsiadów i środka ciężkości. Można to uczynić np. zaraz po wyznaczeniu samej siatki. Dzięki temu unika się wielokrotnego szukania sąsiadów danego elementu.

Uzyskane tunele wrażliwości odzwierciedlają tylko wpływ poszczególnych wokseli (tj. pojedynczych przestrzennych elementów zdyskretyzowanej przestrzeni pomiarowej czujnika ECT np. czworościanów) na projekcję poszczególnych strumieni tj. linii sił pola elektrycznego $\mathrm{z}$ uwzględnieniem przestrzennego rozkładu przenikalności elektrycznej. Natomiast nie oddają jeszcze w pełni charakterystyki tego układu. Mianowicie tego, że wrażliwość układu jest znacznie mniejsza w jego środku 
w porównaniu do obszarów znajdujących się w pobliżu elektrod. Owszem, nowe mapy wrażliwości w danej chwili uwidaczniają zwiększony obszar wrażliwości w pobliżu elektrod w stosunku do centrum całego układu, ale tylko w znaczeniu obszarowym, natomiast wartości wag w obrębie lokalnych obszarów są zawsze takie same. Aby to zmienić, do algorytmu metody tunelowej należało wprowadzić kolejny ostatni etap. Polega on na wyznaczeniu dodatkowych map wag dla każdego woksela obrazu w postaci współczynników odległości od elektrod E i G i przemnożeniu ich przez odpowiadające im obszary wrażliwości z map uzyskanych metodą tunelową. Mapy tych wag można wyznaczyć korzystając z następującego wzoru:

$$
S_{i j}=\left(\frac{1}{d_{S}}+\frac{1}{d_{R}}\right)^{2}
$$

gdzie $d_{S}$ i $d_{R}$ to odległości punktu od elektrody odpowiednio nasyconej i uziemionej (patrz rysunek 4).

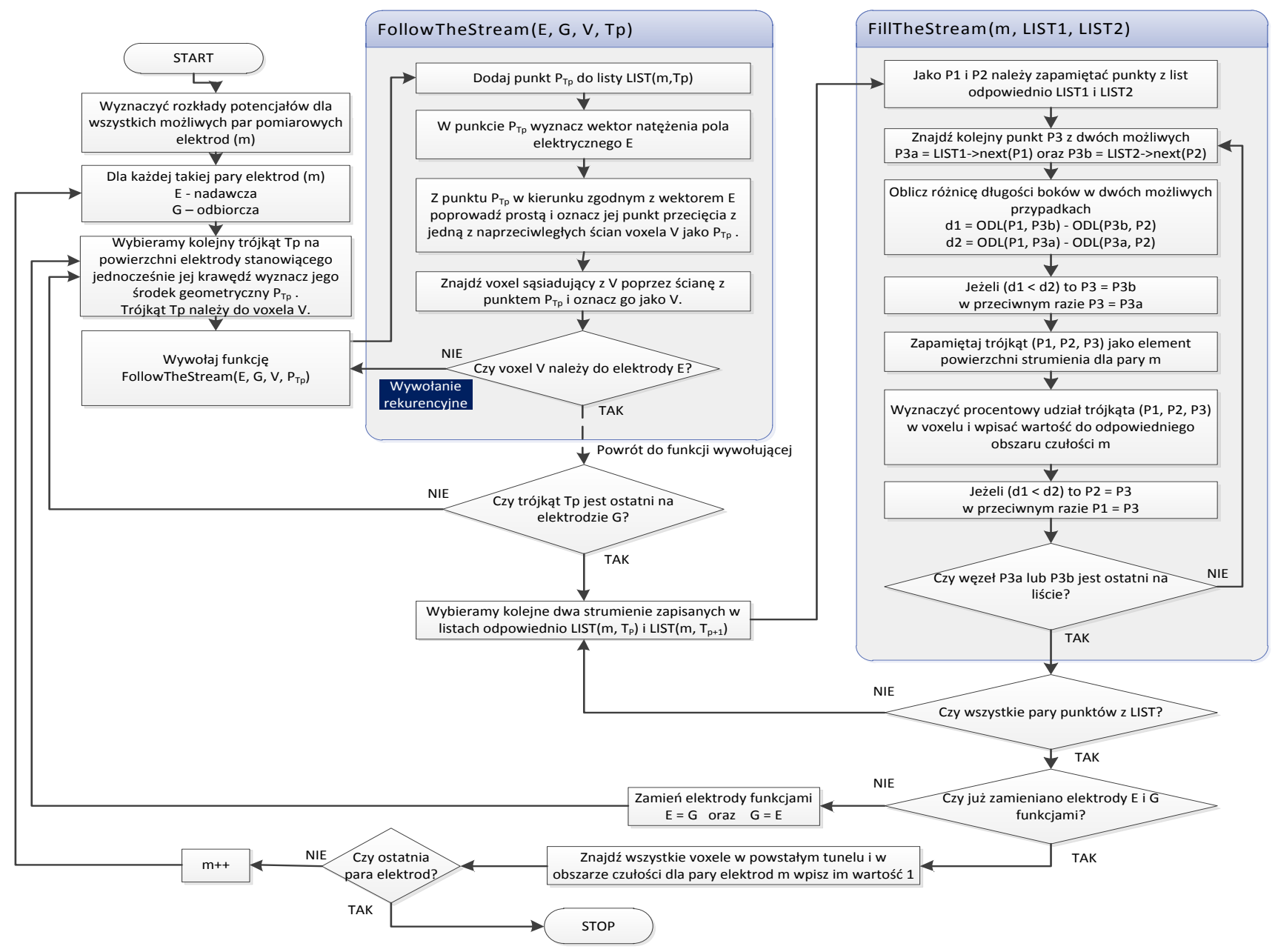

Rys. 3. Sieć działań algorytmu metody tunelowej wyznaczania macierzy wrażliwości

Gdy wszystkie elementy nowej mapy wrażliwości mają już przypisaną odpowiednią wartość, cała mapa jest normalizowana [11].
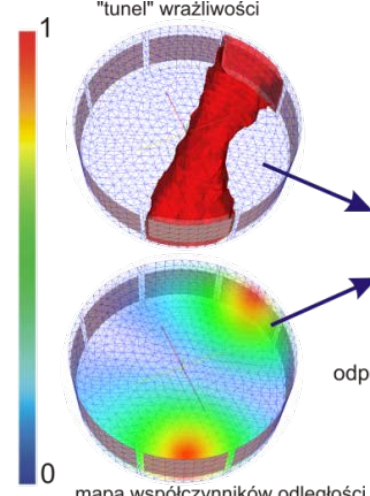

Rys. 4. Ostateczny etap wyznaczania macierzy wrażliwości metoda tunelowa polegający na przemnożeniu obszarów tuneli wrażliwości przez wspótczynniki wag odlegtości wokseli siatki od elektrod (skala kolorów wyraża wartość wrażliwości w jednostkach względnych)

\section{Eksperymenty i wyniki}

W tym rozdziale opisano przeprowadzone eksperymenty i przedstawiono wyniki działania nowych macierzy wrażliwości wyznaczanych metodą tunelową w procesie rekonstrukcji obrazów $\mathrm{w}$ porównaniu $\mathrm{z}$ użyciem tradycyjnych macierzy wrażliwości wyznaczanych w oparciu o zależności matematyczno-fizyczne wynikające z równania Laplace’a. Do oceny obrazów zostały przyjęte następujące kryteria:

- znormalizowany średni błąd kwadratowy obrazu (NMSE Normalized Mean Square Error), który pozwala wyznaczyć różnicę pomiędzy zadaną (fantom) i skonstruowaną wartością przenikalności elektrycznej dla danego woksela (obraz) opisany jest zależnością [13]:

$$
\delta d=\sqrt{\frac{\sum_{i=1}^{N}\left(\varepsilon_{i}-\hat{\varepsilon}_{i}\right)^{2}}{\sum_{i=1}^{N}\left(\varepsilon_{i}-\bar{\varepsilon}\right)^{2}}}
$$


- współczynnik liniowej korelacji Pearsona, który pozwala ocenić zależność liniową pomiędzy zadaną a skonstruowaną wartością przenikalności elektrycznej dla poszczególnych elementów obrazu - wyrażony wzorem [13]:

$$
R=\frac{\sum_{i=1}^{N}\left(\hat{\varepsilon}_{i}-\overline{\hat{\varepsilon}}\right)\left(\varepsilon_{i}-\bar{\varepsilon}\right)}{\sqrt{\sum_{i=1}^{N}\left(\hat{\varepsilon}_{i}-\overline{\hat{\varepsilon}}\right)^{2} \sum_{i=1}^{N}\left(\varepsilon_{i}-\bar{\varepsilon}\right)^{2}}}
$$

gdzie wektor $\boldsymbol{\varepsilon}$ (zdefiniowany jako jednokolumnowa macierz) jest zakładanym (w przypadku symulacji) a $\hat{\boldsymbol{\varepsilon}}$ jest zrekonstruowanym znormalizowanym rozkładem przenikalności. Wartości $\varepsilon_{i}$ oraz $\hat{\varepsilon}_{i}$ są elementami wektorów odpowiednio $\varepsilon$ oraz $\hat{\boldsymbol{\varepsilon}}$. Wartości $\bar{\varepsilon}$ oraz $\overline{\hat{\varepsilon}}$ to wartości średnie wszystkich elementów wektorów odpowiednio $\boldsymbol{\varepsilon}$ oraz $\hat{\boldsymbol{\varepsilon}}$.

Aby możliwe było oszacowanie wartości błędów i zastosowanie powyższych kryteriów oceny, proces rekonstrukcji obrazów został przeprowadzony $\mathrm{m}$. in. dla zasymulowanego przestrzennego rozkładu przenikalności elektrycznej przedstawionego na rysunku 5.

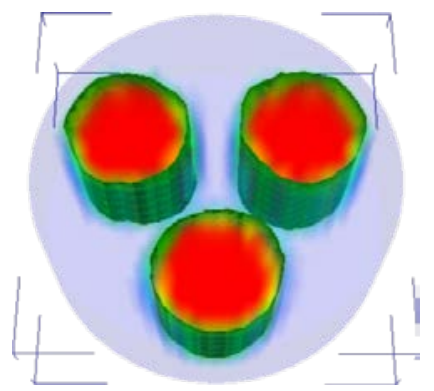

Rys. 5. Uzyty do badań zasymulowany przestrzenny rozkład przenikalności elektrycznej

W przypadku pomiarów na rzeczywistych obiektach nie jest możliwe opracowanie wiarygodnego referencyjnego modelu rozkładu materiału, który należy podać do zdefiniowanych powyżej kryteriów oceny. Dla potrzeb eksperymentu - symulacji wykorzystana została liniowa metoda iteracji Landwebera [1]. Za każdym razem przeprowadzonych zostało 400 iteracji przy czym w celu wykazania szybkości zbieżności metody, do prezentacji wyników wybierane były obrazy po $25,100,200$ i 400 iteracjach. Jednocześnie, po każdej iteracji wyznaczane były: błąd średni kwadratowy oraz współczynnik korelacji liniowej. Wyniki przeprowadzonych eksperymentów oraz obliczonych wartości przyjętych kryteriów oceny zostały zaprezentowane na wykresach - Rysunki 6 do 9.

Symbole/skróty na rysunkach oznaczają:

- J_FE - w procesie rekonstrukcji zastosowano klasyczne macierze wrażliwości wyliczane $\mathrm{z}$ energii pola elektrycznego (ang. Filed Energy);

- J_EFS - w procesie rekonstrukcji zastosowano tunelowe macierze wrażliwości (ang. Electrical Field Surfaces);

- RF - (ang. relaxation factor) współczynnik relaksacji (agresywności) metody rekonstrukcji obrazów.

W artykule zdecydowano się przedstawić tylko dwa spośród wielu przeprowadzonych eksperymentów. W każdym $\mathrm{z}$ nich wykazana została zwiększona szybkość zbieżności w przypadku zastosowania tunelowych macierzy wrażliwości. Cecha ta uwydatnia się bardziej $\mathrm{z}$ chwilą zwiększania agresywności procesu rekonstrukcji (tj. zwiększanie współczynnika relaksacji). Warto zauważyć, że dla dużej agresywności procesu w przypadku klasycznych macierzy wrażliwości ostatecznie metoda traci swoją zbieżność, a błędy rekonstrukcji z każdą iteracją powiększają się.

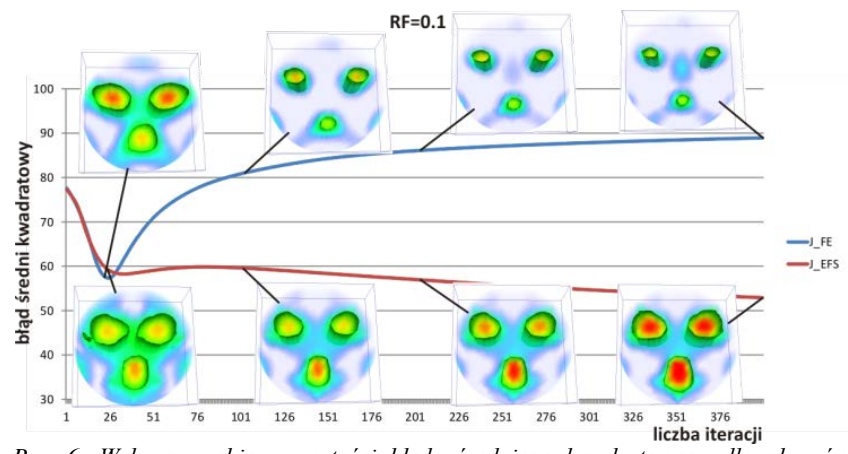

Rys. 6. Wykres przebiegu wartości błędu średniego kwadratowego dla obrazów otrzymanych $w$ wyniku zastosowania metody iteracji Landwebera przy $R F=0.1$ w funkcji liczby iteracji z użciem klasycznych $(J F E)$ i tunelowych (J_EFS) macierzy wrażliwości

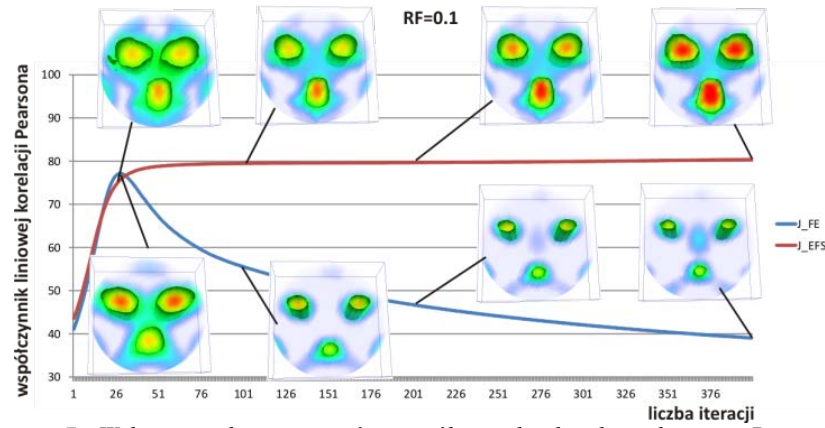

Rys. 7. Wykres przebiegu wartości wspótczynnika korelacji liniowej Pearsona dla obrazów otrzymanych $w$ wyniku zastosowania metody iteracji Landwebera przy $R F=0.1 \mathrm{w}$ funkcji liczby iteracji z uzyciem klasycznych $\left(J \_F E\right)$ i tunelowych (J_EFS) macierzy wrażliwości

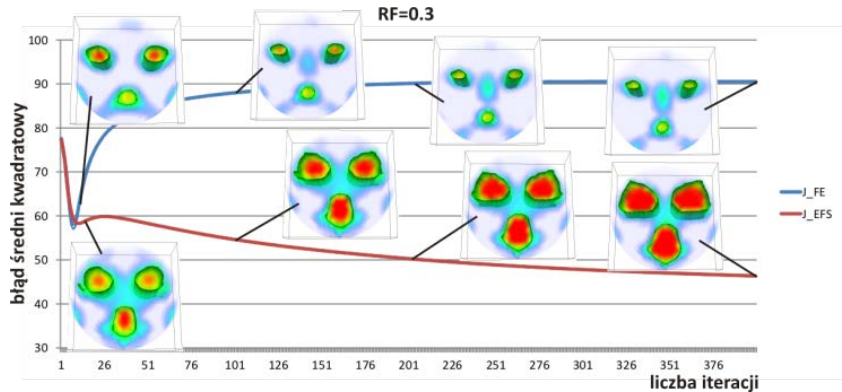

Rys. 8. Wykres przebiegu wartości błędu średniego kwadratowego dla obrazów otrzymanych $w$ wyniku zastosowania metody iteracji Landwebera przy $R F=0.3$ $w$ funkcji liczby iteracji z użyciem klasycznych $\left(J_{-} F E\right)$ i tunelowych (J_EFS) macierzy wrażliwości

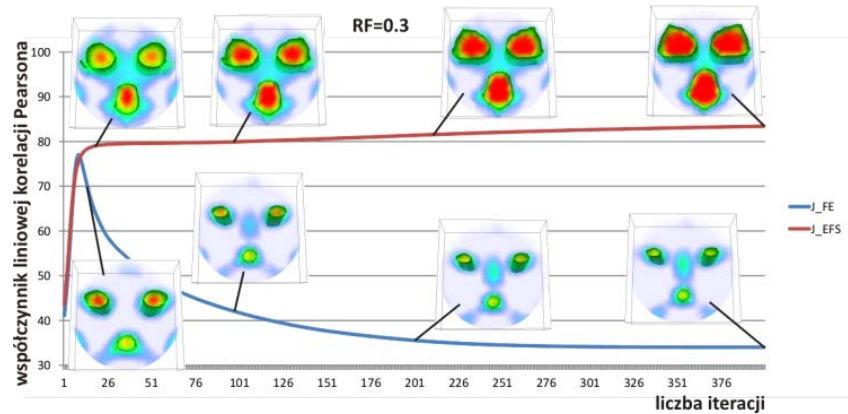

Rys. 9. Wykres przebiegu wartości wspótczynnika korelacji liniowej Pearsona dla obrazów otrzymanych $w$ wyniku zastosowania metody iteracji Landwebera przy $R F=0.3 w$ funkcji liczby iteracji z uzyciem klasycznych $\left(J_{-} F E\right)$ i tunelowych (J EFS) macierzy wrażliwości

Na kolejnym etapie oceny zaproponowanych algorytmów rekonstrukcji w tym nowej tunelowej metody wyznaczania macierzy wrażliwości, dokonano jej integracji z przedstawionym na Rysunku 1 algorytmem nieliniowej rekonstrukcji obrazu. Zrealizowano rzeczywiste pomiary tomograficzne przepływu mieszaniny dwufazowej w sekcjach poziomej i pionowej [6] i na ich podstawie zrekonstruowano obrazy ponownie $\mathrm{w}$ oparciu o tunelowe (J_EFS) oraz klasyczne (J_FE) macierze wrażliwości. 
Wybrane wyniki tych badań zostały zestawione na rysunku 10 (na następnej stronie). Podobnie i w tym przypadku obrazy uzyskane dla przypadku macierzy tunelowych wykazują lepsze odwzorowanie rzeczywistych struktur przepływu w obrazach tomograficznych.

W celu dokonania oceny metrologicznej zaproponowanej metody zasymulowano dodatkowo dwa rozkłady przenikalności elektrycznej (fantom) odpowiadające 50\% wypełnieniu cieczą o stałej elektrycznej 37.0 rurociągu poziomego o średnicy zewnętrznej $90 \mathrm{~mm}$ oraz $50 \%$ wypełnieniu cieczą o stałej elektrycznej 37.0 rurociągu pionowego o średnicy zewnętrznej 40 $\mathrm{mm}$. Następnie dokonano akwizycji danych $\mathrm{z}$ rzeczywistego czujnika ECT 3D. Obraz fantomu oraz obraz zrekonstruowany na bazie danych eksperymentalnych dla sekcji poziomej i pionowej przedstawia rysunek 11 (na następnej stronie).

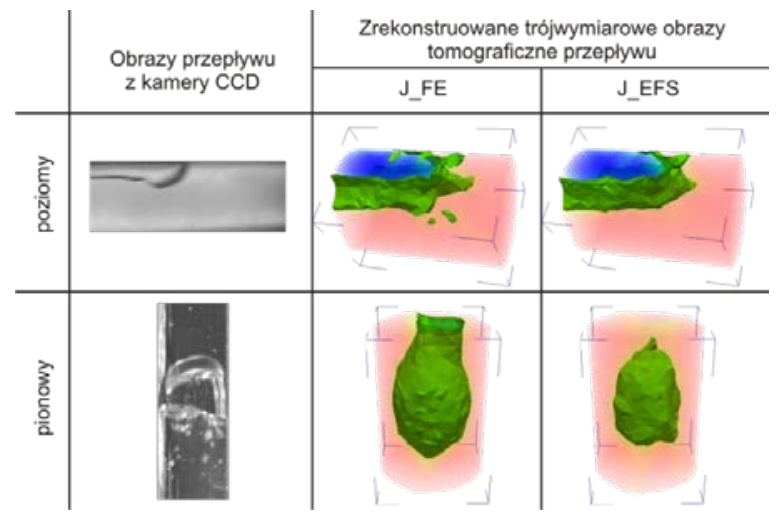

Rys. 10. Wyniki rekonstrukcji obrazów danych pomiarowych zrealizowanych dla przeplywu mieszaniny dwufazowej przy zastosowaniu klasycznych (J_FE) i tunelowych (J_EFS) macierzy wrażliwości na tle obrazów zarejestrowanych kamera $C C D$

Zrekonstruowane obrazy znormalizowano i wyznaczono pomiędzy nimi znormalizowany średni błąd kwadratowy obrazu (NMSE): $29.24 \%$ oraz współczynnik liniowej korelacji Pearsona: 91.93\%. Dla sekcji poziomej uzyskano wyniki: średni błą kwadratowy obrazu (NMSE): $32.80 \%$ oraz współczynnik liniowej korelacji Pearsona: $88.61 \%$. Pomimo relatywnie dużej wartości błędu NMSE, która może być wynikiem występowania zjawiska „przesunięcia” opracowanego, przestrzennego fantomu i rzeczywistego zrekonstruowanego rozkładu przenikalności elektrycznej, współczynnik liniowej korelacji potwierdza teoretycznie wysoką skuteczność opracowanego algorytmu tunelowego wyznaczania macierzy wrażliwości dla procesu rekonstrukcji obrazów trójwymiarowych.
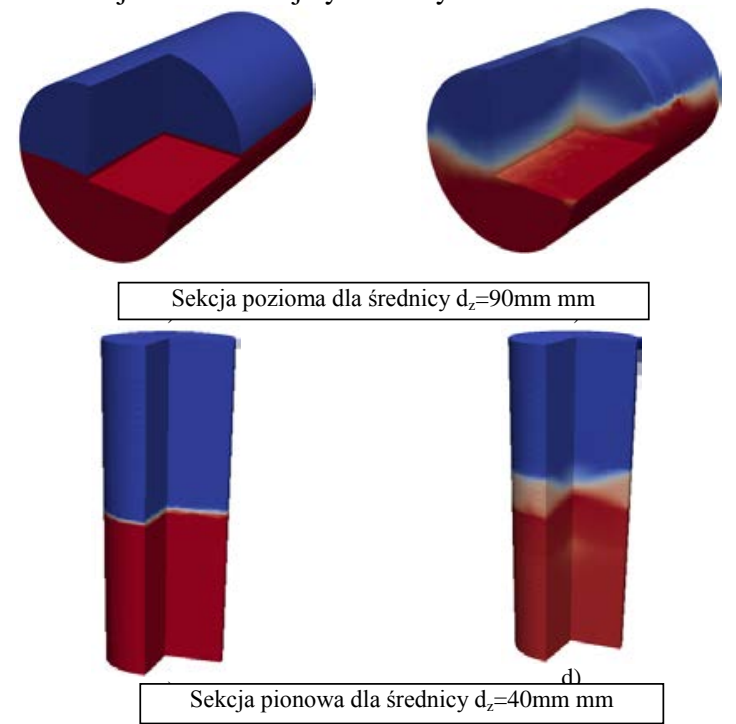

Rys. 11. Obrazy 3D fantomu a) i c) oraz obrazy zrekonstruowany na bazie danych eksperymentalnych b) $i$ d) - przygotowane $w$ celu oceny skuteczności opracowanych algorytmów

\section{Wiarygodność przyjętych kryteriów oceny}

Interpretacja wyników zastosowania miar porównawczych dla przeprowadzonych eksperymentów poddaje jednakże pod rozwagę jedną wątpliwość: skąd tak duże względne wartości całkowitego błędu obrazu przy jednocześnie spodziewanych wysokich wartościach współczynnika korelacji liniowej [1]? W przypadku zagadnienia 3D porównuje się obrazy liczące najczęściej kilkadziesiąt tysięcy elementów. Współczynnik liniowej korelacji Pearsona może, dla tak licznej populacji danych, wykazywać duże podobieństwo pomiędzy porównywanymi obrazami mimo występowania licznych lokalnych, czasami dużych rozbieżności pomiędzy zadaną a konstruowaną wartością przenikalności elektrycznej. Średni błąd kwadratowy obrazu jest znacznie bardziej wrażliwy na występowanie dużych różnic pomiędzy fantomem a obrazem skonstruowanym. Wyznaczenie średniego błędu kwadratowego obrazu polega na bezpośrednim porównaniu wartości znormalizowanej przenikalności elektrycznej dla odpowiadających sobie elementów obrazu fantomu i obrazu uzyskanego $\mathrm{w}$ oparciu o rzeczywisty pomiar. Możliwe jest również występowanie błędów konstrukcji obrazu, które powodują lokalne przesunięcia konstruowanego rozkładu przenikalności elektrycznej względem zadanego fantomu. W efekcie, widziany przez obserwatora konstruowany obraz 3D wykazuje cechy zgodności ze wzorcem (fantomem) lecz zastosowanie obiektywnych kryteriów tego nie potwierdza. Duży wpływ na wartość błędu obrazu mogą wywierać zniekształcenia występujące dla obiektów zlokalizowanych w okolicach skrajnych płaszczyzn pomiarowych. Występują tam obszary słabiej skanowane przez pomiary międzyelektrodowe. W konsekwencji, obiekty konstruowane w tych obszarach, mogą powodować silne zaburzenia kształtu oraz może pojawić się efekt „rozciągania” obiektów w kierunku granic obszaru pomiarowego. Podobny wpływ na dużą wartość błędu obrazu mogą mieć zaburzenia obrazu w obszarach pomiędzy płaszczyznami pomiarowymi. Przykład omówionych przyczyn występowania dużych błędów konstrukcji obrazu zaprezentowano na rysunku 12. Przedstawia on obraz 3D fantomu przenikalności elektrycznej złożonego z 9 kul rozmieszczonych w przestrzeni pomiarowej, skonstruowany obraz $3 \mathrm{D}$ oraz nałożone na siebie te dwa obrazy.
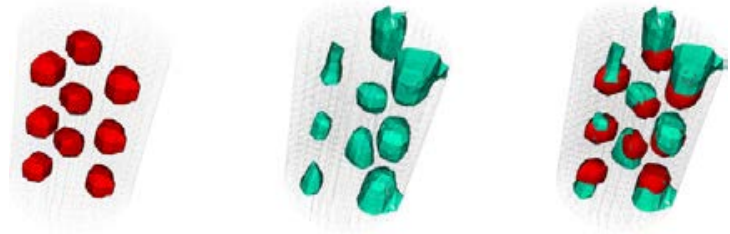

Rys. 12. Przykladowa wizualizacja przedstawiajaca trzy obrazy: a - obraz fantomu oznaczony kolorem czerwonym, $b$ - konstrukcje obrazu $3 D w$ kolorze zielonym, $c$-obraz 3 D powstaly z natożenia na siebie obrazów a i b

Obraz 3D przedstawiony na rysunku 12 (c) powstał w wyniku nałożenia na siebie wizualizacji fantomu (a) oraz wizualizacji konstrukcji obrazu (b). Analizując tylko wynik konstrukcji obrazu przedstawiony na (b) czytelnik może odnieść wrażenie, iż obraz został skonstruowany poprawnie, gdyż bez trudu możliwe jest, przy zastosowaniu oceny wzrokowej, wydzielenie obszarów o różnych wartościach przenikalności elektrycznej. Po połączeniu ze sobą obrazów (a) i (b) widoczne są znaczące różnice pomiędzy odpowiadającymi sobie elementami tych obrazów. Na obrazie (c) można zauważyć zarówno zjawisko ,przesunięcia” przestrzennego obrazów jak i problem zniekształceń w skrajnych strefach obrazowania. W obszarach obrazu pokrywających się błąd będzie niewielki i związany z dokładnością odtworzenia w tych punktach wartości przenikalności elektrycznej. W obszarach, w których obrazy się nie pokrywają, nastąpi gwałtowny wzrost wartości błędu. Omówione problemy mogą zaowocować silnym wzrostem sumarycznego błędu obrazu mimo pozytywnej, subiektywnej oceny wzrokowej. 


\section{Podsumowanie}

W artykule przedstawiono przebieg i wyniki przeprowadzonych eksperymentów rekonstrukcji obrazów $\mathrm{z}$ użyciem systemu trójwymiarowej tomografii pojemnościowej. Zastosowano macierze wrażliwości wyliczane nową tunelową metodę działająca na bazie algorytmu śledzenia powierzchni budowanych wzdłuż linii sił pola elektrycznego. Dzięki takiemu zastosowaniu wyniki rekonstrukcji są znacząco lepszej jakości. Wyniki przeprowadzonych eksperymentów potwierdziły dużo większą zbieżność procesu rekonstrukcji w przypadku zastosowania nowych macierzy wrażliwości. Opracowana metoda została już z sukcesem wdrożona do zakończonego projektu, którego celem było opracowanie systemu pomiarowego 3D ECT do identyfikacji struktur i wyznaczania procentowego udziału faz mieszanin typu gaz-ciecz w rurociągach poziomych oraz pionowych.

\section{Podziękowania}

Prace opisane w ramach niniejszego artykułu są finansowane z rządowego projektu badawczego $\mathrm{nr}$ 4664/B/T02/2010/38.

\section{Literatura}

[1] Banasiak R.: Algorytmy wizualizacji 3D w przemysłowych systemach elektrycznej tomografii procesowej; Praca doktorska, Politechnika Łódzka, Łódź, 2007.

[2] Banasiak R., Wajman R., Sankowski D., Soleimani M.: Three-dimensional nonlinear inversion of electrical capacitance tomography data using a complete sensor model. Progress In Electromagnetics Research PIER, 100, 2010, pp. 219234.

[3] Dyakowski T.: Process tomography applied to multi-phase flow measurement. Meas. Sci. Technol. 7/1996, pp. 343-353.

[4] Loser T., Wajman R., Mewes D. 2001 Electrical capacitance tomography: image reconstruction along electrical field lines, Meas. Sci. Technol. 2001, vol. $12 \mathrm{nr} 8$ pp. 1083-1091.

[5] Olszewski T., Kleczyński P., Brzeski P., Mirkowski J., Pląskowski A., Smolik W., Szabatin R.: Electrical capacitance tomograph design; 3rd International Symposium on Process Tomography in Poland, Łódź, 2004 s. 118-123.

[6] Rzasa M.R. The Stand For Tests of Gas-Liquid Flow Structure; 3rd International Symposium on Process Tomography in Poland, Łódź 2004, s. 139-142.
[7] Sikora J. Algorytmy numeryczne w tomografii impedancyjnej. Oficyna Wydawnicza Politechniki Warszawskiej, Warszawa 2000.

[8] Wajman R.: Nowa metoda rekonstrukcji obrazów dla potrzeb pojemnościowej tomografii procesowej, Praca doktorska, Politechnika Łódzka, Łódź 2006.

[9] Wang H.G., Liu S., Jiang F., Yang W.Q. 3D Presentation of Images with Capacitance Tomography; 3rd World Congress on Industrial Process Tomography, Banff, Canada 2003, s. 331-336.

[10]Williams R.A., Beck M.S. Process tomography: principles, techniques and applications. BH, Oxford 1995.

[11] Xie C.G., Huang S.M., Hayes D.G., Gregory I.A., Beck C.M.: Transputer/DSPbased capacitance tomography for real-time imaging and velocity profile measurement of oilfield flow pipelines; Parallel Computing and Transputer Appl., Edts. M.S. Beck u.a. 1994, pp. 123-134.

[12]Yang W.Q. and Peng L.: Review of image reconstruction algorithms for electrical capacitance tomography, Part 1, Principles, proc International Symposium on Process Tomography in Poland, Wrocław 2002, pp. 123-132.

[13] Yang W.Q., Peng L.: Image reconstruction algorithms for electrical capacitance tomography; Meas. Sci. Technol. 2003, Vol. 14, No. 1, pp. R1-R13.

[14]Zienkiewicz O.C. Metoda Elementów Skończonych; Arkady Warszawa 1972.

\section{Dr inż. Radosław Wajman \\ e-mail: rwajman@kis.p.lodz.pl}

Dr inż. Radosław Wajman jest adiunktem w Instytucie Informatyki Stosowanej Politechniki Łódzkiej. Prowadzone badania skupiają się nad zastosowaniem systemów trójwymiarowej tomografii pojemnościowej do nieinwazyjnego monitorowania, diagnozowania oraz automatycznego sterowania praca przemysłowych instalacji transportu pneumatycznego materiałów sypkich oraz przepływu dwu-fazowego gaz-ciecz.

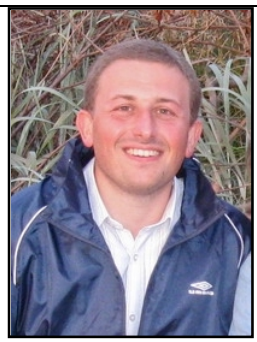

Dr inż. Robert Banasiak

e-mail: robert.banasiak@p.lodz.pl

Dr inż. Robert Banasiak jest adiunktem w Instytucie Informatyki Stosowanej Politechniki Łódzkiej. W swoich pracach zajmuje się przemysłowymi zastosowaniami elektrycznej tomografii procesowej, a w szczególności problematyką rekonstrukcji obrazów oraz modelowania numerycznego systemów tomografii pojemnościowej. Kierownik grantu 4664/B/T02/2010/38.

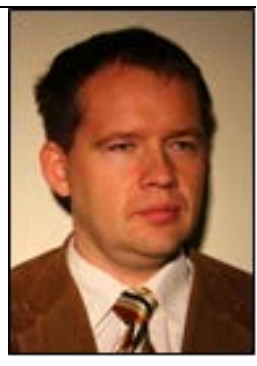

otrzymano/received: 25.03 .2013

\section{Administrowanie Sieciami Komputerowymi}

\section{Politechnika Lubelska}

Instytut Elektroniki i Technik Informacyjnych

\section{Dwusemestralne studia podyplomowe obejmują moduły kształcenia:}

1 Podstawy administrowania systemem Windows

2 Podstawy administrowania systemem Linux

3 Sieci LAN

4 Sieci IP

5 Routing w sieciach IP

6 Sieci TCP/IP

7 Usługi w sieciach TCP/IP

8 Wykorzystanie Windows w sieciach LAN

9 Wykorzystanie Linux w sieciach LAN

10 Zarządzanie systemami informatycznymi

11 Sieci telekomunikacyjne
12 Serwery usług sieciowych

13 Bezpieczeństwo systemów komputerowych

14 Diagnostyka sieci komputerowych

15 Multimedia strumieniowe

16 Systemy telefonii VoIP

17 Sieci dostępowe

18 Kodowanie informacji multimedialnych

19 Elementy sieci optoelektronicznych

20 Światłowody i kable światłowodowe

21 Podstawy normalizacji

22 Seminarium dyplomowe

Telefon:

(0-81) 5384309 - sekretariat Instytutu Elektroniki i Technik Informacyjnych

(0-81) 5384317 - opiekun ds. organizacyjnych, dr inż. Piotr Kisała

Faks:

(0-81) 5384312

\section{Poczta elektroniczna}

ask@politechnika.lublin.pl

Adres pocztowy:

ul. Nadbystrzycka 38A, 20-618 Lublin 